Jurnal Health Sains: p-ISSN: 2723-4339 e-ISSN: 2548-1398

Vol. 2, No. 6, Juni 2021

\title{
FAKTOR FAKTOR YANG BERHUBUNGAN DENGAN PELAKSANAAN TEKNIK MENYUSUI DENGAN BENAR PADA IBU MENYUSUI
}

\section{Bara Miradwayana, Suryati, Fenti Hasnani}

Politeknik Kesehatan Kemenkes Jakarta I, Indonesia

Email: baramiradwiyana@gmail.com, suryatisuripto@yahoo.com, fentihasni112@gmail.com

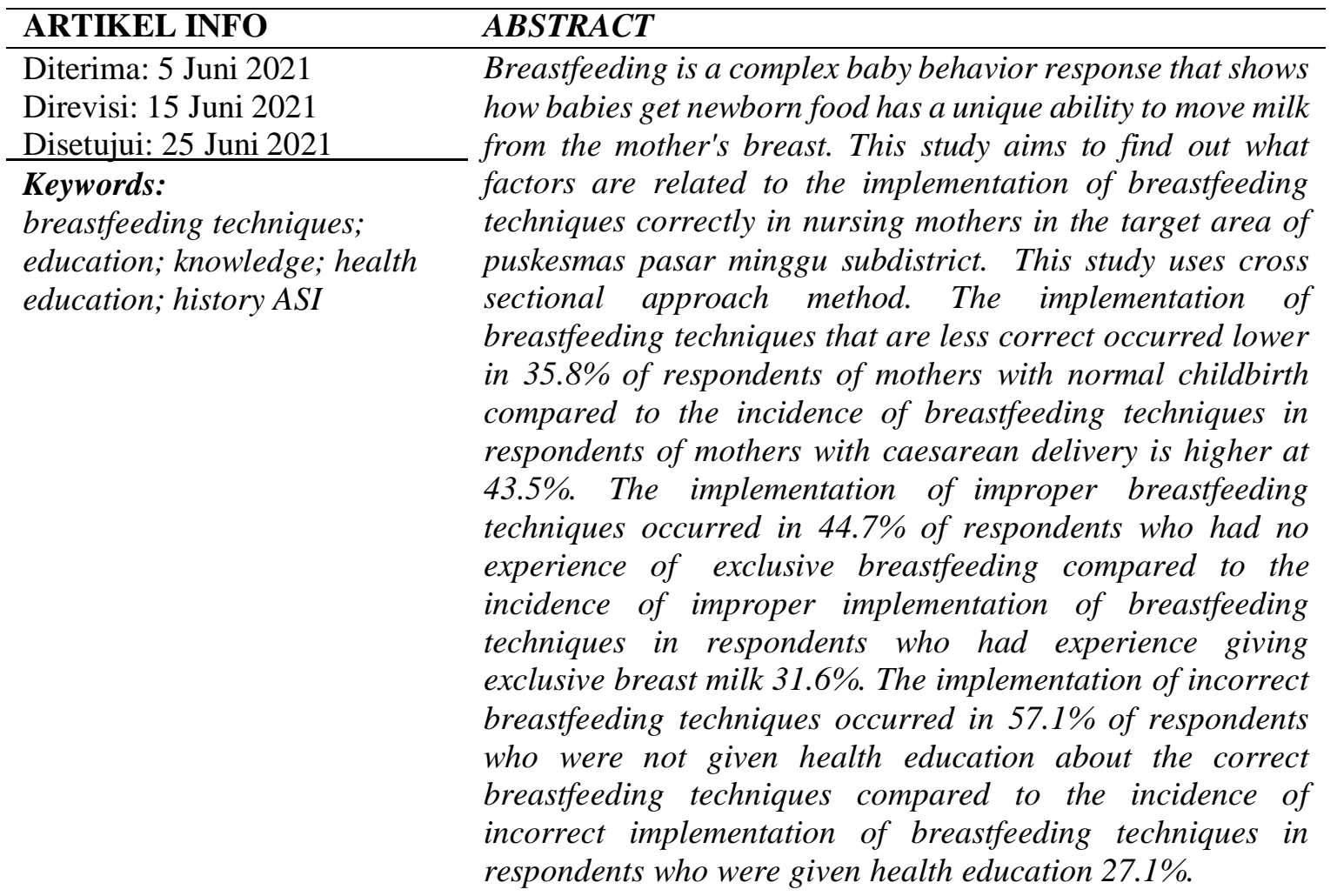

\begin{abstract}
ABSTRAK
Menyusu merupakan respon perilaku bayi yang komplek yang menunjukan cara bayi memperoleh makanan bayi baru lahir mempunyai kemampuan yang unik yaitu mampu memindahkan susu dari payudara ibunya. Penelitian ini bertujuan untuk mengetahui faktor-faktor apa saja yang berhubungan dengan pelaksanaan tehnik menyusui dengan benar pada ibu menyusui di wilayah binaan puskesmas kecamatan pasar minggu. Penelitian ini menggunakan metode pendekatan cross sectional. Pelaksanaan teknik menyusui yang kurang benar terjadi lebih rendah pada 35.8\% responden ibu dengan persalinan normal dibandingkan dengan kejadian pelaksanaan tehnik menyusui pada responden ibu dengan persalinan secara caesar yang lebih tinggi yaitu $43.5 \%$. Pelaksanaan teknik menyusui yang kurang benar terjadi pada $44.7 \%$ responden yang tidak
\end{abstract}

\begin{tabular}{lllll}
\hline How to cite: & Miradwayana, Bara. et, al. (2021) Faktor Faktor yang Berhubungan dengan Pelaksanaan Teknik \\
& Menyusui dengan Benar pada Ibu Menyusui. Jurnal Health Sains 2(6). \\
& https://doi.org/10.46799/jhs.v2i6.193 & & & \\
E-ISSN: & $2723-6927$ & & & \\
Published by: & Ridwan Institute & & & \\
\end{tabular}


Kata Kunci:

teknik menyusui; pendidikan; pengetahuan; pendidikan kesehatan; riwayat ASI mempunyai pengalaman memberikan ASI eksklusif dibandingkan dengan kejadian pelaksanaan teknik menyusui yang kurang benar pada responden yang mempunyai pengalaman memberikan ASI ekslusif 31.6\%. Pelaksanaan teknik menyusui yang kurang benar terjadi pada $57.1 \%$ responden yang tidak diberikan pendidikan kesehatan tentang teknik menyusui yang benar dibandingkan dengan kejadian pelaksanaan tehnik menyusui yang kurang benar pada responden yang diberikan pendidikan kesehatan $27.1 \%$.

\section{Pendahuluan}

Menyusu merupakan respon perilaku bayi yang komplek yang menunjukan cara bayi memperoleh makanan bayi baru lahir mempunyai kemampuan yang unik yaitu mampu memindahkan susu dari payudara ibunya. Bayi menunjukan adaptasi yang luar biasa (Sembiring, 2019). Pertumbuhan dan perkembangan bayi sebagian besar ditentukan oleh jumlah ASI yang diper oleh termasuk energi dan zat gizi lainnya yang terkandung di dalam ASI tersebut. ASI tanpa bahan makanan lain dapat mencukupi kebutuhan pertumbuhan sampai usia sekitar empat bulan (Merryana Adriani, 2016).

Pencapaian ASI eksklusif hingga saat ini belum mengembirakan. Hal ini karena ibu kurang percaya diri bila ASI nya cukup untuk bayinya (Balqis, 2020). Kurangnya pengetahuan ibu tentang cara menyusui yang baik dan benar, kurangnya pengertian dan ketrampilan petugas kesehatan tentang keunggulan ASI dan manfaat menyusui menyebabkan mereka mudah terpengaruhi oleh promosi susu formula yang sering dinyatakan sebagai Pengganti Air Susu Ibu (Muliawati, 2016). Kurangnya pengetahuan tentang tehnik menyusui yang benar juga merupakan salah satu faktor yang mempengaruhi pemberian ASI pada bayi (Arifiati, 2017).

Gambaran pemberian ASI di Indonesia berdasarkan SDKI (Wilopo, 2009) yaitu $32,3 \%$, masih jauh dari rata-rata dunia yaitu $38 \%$ (Asiah, 2016). Saat ini bayi kurang dari 6 bulan yang diberi susu formula meningkat dari $16,7 \%$ tahun 2002 menjadi $27.9 \%$ pada tahun 2007. Di Jateng pemberian ASI eksklusif adalah $34,53 \%$, di Semarang 13,49\% tahun 2006 menurun menjadi 7,74\% tahun 2008.

Hasil survey (Kemenkes, 2018) terjadi peningkatan dalam pemberian ASI ekslusif sampai dengan 6 bulan. Pada tahun 2010 sebesar $15.3 \%$ meningkat menjadi $30.2 \%$. Walaupun demikian masih lebih sedikit dibandingkan dengan ibu yang memberikan ASI ekslusif padabulan-bulan pertama.

Teknik menyusui merupakan salah satu faktor yang mempengaruhi produksi ASI dimana bila teknik menyusui tidak benar, dapat menyebabkan puting lecet sehingga menjadikan ibu enggan menyusui dan bayi jarang menyusu sering kali paru ibu kurang mendapatkan informasi tentang manfaat ASI dan teknik menyusui memang benar(Angsuko, 2009). Menyusui yang terbaik untuk bayi karena ASI mudah dicerna dan memberikan gizi dalam jumlah yang cukup untuk kebutuhan bayi (Wulandari \& Iriana, 2016). Air susu ibu membantu melindungi bayi dari berbagai penyakit dan infeksi, membantu mencegah alergi makanan (Maghfiroh, 2018). Menyusui lebih yaman dan lebilı murah dari pada susu formula. ASI selalu siap dan pada suhu yang stabil dengan temperatur tubuh. Pada keadaan normal semua wanita dapat menyusui. Dukungan darikeluarga dan temanteman akan membantu suksesnya menyusui. Menyusui merupakan kewajiban bagi setiap ibu yang melahirkan bayi (Hani, 2014). Menyusui juga merupakan 
wujud kasih sayang yang diberikan seorang ibu kepada bayinya. Dengan menyusui, berarti ibu sudah memberikan hal yang sangat berharga kepada bayinya karena Air Susu Ibu (ASI) adalah satu-satunya makanan yang dibutuhkan oleh si kecil (Hayati, 2018).

Tujuan penelitian ini dilakukan untuk mengetahui faktor-faktor yang berhubungan dengan pelaksanaan teknik menyusui dengan benar pada ibu menmyusui di wilayah binaan puskesmas kecamatan pasar minggu.

\section{Metode Penelitian}

Jenis penelitian yang digunakan dalam penelitian ini adalah observasional yang bersifat analitik, teknik pengambilan data secara cross sectional. Penelitiandilaksanakan di Wilayah binaan Puskesmas Kecamatan Pasar Minggu Jakarta Selatan pada bulan September - November 2014. Populasi adalah setiap subjek yang memenuhi kritena yang telah ditetapkan (Nursalam, 2011). Populasi Target adalah populasi yang menjadi sasaran aktif yang parameternya akan diketahui melalui penelitian. Dalam penelitianini yaitu ibu menyusui. Sampel adalah bagian dari populasi yang dileliu dan diankitapmewakili seluruh populasi (Nursalam, 2011). Pada penelitian ini sampai diambil dari sebagian ibu-ibu yang berada diwilayah binaan puskesmas kecamatan pasar minggu yang memenuhi kriteria inklusi. Dalam penelitian ini bentuk teknik sampling yang digunakan adalah random sampling.

\section{Hasil dan Pembahasan}

\section{A. Hasil Penelitian}

\section{Analisis Univariat}

Hasil penelitian tentang distribusi karakteristik responden dan variabel penelitian yang dilakukan analisis univariat adalah seperti tercantumdalam tabel 1 .
Tabel 1

Distribusi Responden Menurut

Masing Masing Variabel Apada Ibu

Menyusui Puskesmas Kecamatan

Pasar Minggu Jakarta Selatan

\begin{tabular}{|c|c|c|}
\hline Variabel & n & $\%$ \\
\hline \multicolumn{3}{|l|}{ Pendidikan } \\
\hline Perguruan Tinggi & 15 & 19.7 \\
\hline SMA & 49 & 64.5 \\
\hline SMP & 12 & 15.8 \\
\hline \multicolumn{3}{|l|}{ Pengetahuan } \\
\hline Baik & 37 & 48.7 \\
\hline Kurang & 39 & 51.3 \\
\hline \multicolumn{3}{|l|}{ Proses Persalinan } \\
\hline Normal & 53 & 69.7 \\
\hline Caesar & 23 & 30.3 \\
\hline \multicolumn{3}{|l|}{ Pengalaman ASI } \\
\hline Pengalaman & 38 & 50 \\
\hline Tidak Pengalaman & 38 & 50 \\
\hline \multicolumn{3}{|l|}{ Dukungan Keluarga } \\
\hline Didukung & 76 & 100 \\
\hline Tidak Di Dukung & 0 & 0 \\
\hline \multicolumn{3}{|l|}{ Mendapat Penkes } \\
\hline Diberikan & 48 & 63.2 \\
\hline Tidak Diberikan & 28 & 36.8 \\
\hline \multicolumn{3}{|l|}{ Teknik Menyusui } \\
\hline Benar & 47 & 61.8 \\
\hline Kurang Benar & 29 & 38.2 \\
\hline
\end{tabular}

Distribusi tingkat pendidikan responden lebih banyak yang berasal dari lulusan SMA yaitu 49 orang (64.5\%). Pengetahuan responden tentang tehnik menyusui, ternyatamasih banyak yang masuk kedalam katagori kurang setelah dikelompokan yaitu 39 orang (51.3\%) dibandingkan dengan yang berpengetahuan baik 37 orang (48.7\%).

Distribusi proses melahirkan secara normal lebih banyak dari pada yang melahirkan dengan cara Caesar yaitu 53 orang (69.7\%). Distribusi responden yang mempunyai pengalaman memberikan ASI ekslusif ternyata sebanding dengan distribusi responden yang tidak memberikan ASI eksklusif, masing-masing kelompok berjumlah 38 orang (50\%). Semua responden mendapatkan dukungan dari keluarga untuk dapat menyusui 
Faktor Faktor yang Berhubungan dengan Pelaksanaan Teknik Menyusui dengan Benar pada Ibu Menyusui

anaknya agar mendapat ASI ekslusif 76 orang $(100 \%)$.

Distribusi responden yang pernah mendapat pendidikan kesehatan tentang tehnik menyusui yang benar ada 48 orang $(63.2 \%)$ lebih banyak dari pada yang tidak pernah mendapatkan pendidikan kesehatan 28 orang (36.8\%). Distribusi responden yang dapat melakukan teknik menyusui dengan benar juga lebih besar 47 orang $(61.8 \%)$ daripada responden yang kurang benar dalam melakukan tehnik menyusui 29 orang (38.2\%).

\section{Analisis Bivariat}

Hubungan antara tingkat pendidikan dengan pelaksanaan teknik menyusui yang benar.

\section{Tabel 2}

Distribusi Responden Menurut Pendidikan Dan Teknik Menyusui Di Puskesmas Kecamatan Pasar

\begin{tabular}{cccc}
\multicolumn{3}{c}{ Minggu, Jakarta, Selatan } \\
\hline \multirow{2}{*}{$\begin{array}{c}\text { Pendidikan } \\
\text { Ibu }\end{array}$} & \multicolumn{2}{c}{ Teknik Menyusui } & \\
\cline { 2 - 3 } & Benar & $\begin{array}{c}\text { Kurang } \\
\text { Benar }\end{array}$ & \\
\hline & & $6(40.0 \%)$ & $15(100 \%)$ \\
\hline Tinggi & $9(40.0 \%)$ & $61(100 \%)$ \\
\hline Menengah & $38(62.3 \%)$ & $23(37.7 \%)$ & 6100 \\
\hline Total & $47(61.8 \%)$ & $29(38.2 \%)$ & $76(100 \%)$ \\
\hline
\end{tabular}

Hubungan antara pendidikan dan teknik menyusui dapat dilihat dalam tabel 2 . Hasil analisis didapatkan bahwa kejadian teknik menyusui yang kurang benar terjadi lebih tinggi pada responden dengan pendidikan $40.0 \%$, dibandingkan dengan responden dengan tingkat pendidikan menengah yaitu sebesar $37.7 \%$.

\section{Analisis Multivariat}

Analisis Multivariat menggunakan regresi logistik model prediksi. Tahap pertama yang dilakukan adalah melakukan seleksi bivariat. Hasil dapat dilihat pada tabel 3 selanjutnya dapat dilakukan penilaian confounding.
Tabel 3

Hasil Seleksi Bivariat Regresi

Logistik Pada Pendidikan, Pengetahuan, Proses Persalinan, Pengalaman ASI, Dukungan Keluarga, Pendidikan Kesehatan

\begin{tabular}{lc}
\hline \multicolumn{1}{c}{ Variable } & P value \\
\hline Pendidikan & 0.21 \\
\hline Pengetahuan & 0.003 \\
\hline Proses Persalinan & 0.531 \\
\hline Riwayat Menyusui & 0.237 \\
\hline Dukungan Keluarga & 0 \\
\hline Pendidikan Kesehatan & 0.009 \\
\hline
\end{tabular}

Hasil akhir perhitungan multivariat ternyata yang paling dominan berhubungan adalah faktor pengetahuan dimana ibu yang mempunyai pengetahuan berpeluang 3,4 kali lebih besar untuk melaksanakan teknik menyusui dengan benar.

\section{B. Pembahasan}

Pusat Kesehatan Masyarakat (Puskesmas) yang beralamat di jalan Kebagusan Raya no 4 kecamatan Pasar Minggu, Jakarta Selatan ini berdiri sejak tahun 1995, sebelumnya lokasinya di dekat kantor Polisi Sektor (Polsek) Kecamatan Pasar Minggu. Puskesmas ini merupakan Puskesmas Pusat Kecamatan yang membawahi 10 buah Puskesmaskelurahan diantaranya adalah Puskesmas Kelurahan Pasar Minggu 1, Puskesmas Pasar Minggu 2, Puskesmas Pejaten Barat 1, Puskesmas Pejaten Barat 2, Puskesmas Pejaten Barat 3, Puskesmas Kebagusan, Puskesmas Pejaten Timur, Puskesmas Ragunan, Puskesmas Jati Padang dan Puskesmas Cilandak Timur. Kepala Puskesmas saat ini adalah Drg. Susilowati yang memimpin 121 orang tenaga kesehatan.

Puskesmas ini melayani pasien dengan menyediakan Poliklinik BPJS, Poli Umum, Poli KB, Poli MTBS, Poli Mata, Poli THT, Poli Fisioterapi, Poli Gigi, Poli 
Spesialis Anak, Poli Spesialis Neurologi, Poli Spesialis Mata, Poli Akupuntur, Poli Diabetes Militus (DM), Poli Jiwa, Poli Tindakan Medis, Poli Kulit, Poli TB Paru, Poli Gizi, Poli Haji, Poli IMS dan Laboratorium Umum/BPJS/MTBS. Puskesmas Kecamatan Pasar Minggu juga menyediakan layanan persalinan bagi ibu hamil dengan 1 ruang poliklinik, ruang observasi, ruang melahirkan dan ruang rawat inap khusus ibu melahirkan; selain itu tersedia apotik, layanan untuk lansia, ruang KIA, ruang radiologi dan 24 jam layanan Gawat Darurat. Bagi para pasiennya, Puskesmas ini juga menyelenggarakan senam DM setiap hari Selasa dan Rabu Pukul 08.00 - 09.00 WIB, senam hamil setiap Senin Pukul 07.30 - $08.30 \mathrm{WIB}$, senam hipertensi, senam lansia dan senam peserta Haji. Senam bagi pasien ini diadakan dilantai 3 ruang pertemuan aula. Selain itu juga ada penyuluhan kesehatan untuk ibu hamil yang diberikan di Puskesmas.

Puskesmas ini mendapatkan standarisasi organisasi serta beberapa prestasi diantaranya ISO 9001 - 2000, ISO 9001-2008, juara II GKM 2012 kategori gold tingkat Provinsi DKI Jakarta, juara I Posyandu Pepaya Pejaten Barat, tingkat Kota Jakarta Selatan dan juara IVPosyandu Pepaya Pejaten Barat, tingkat Provinsi DKI Jakarta, juara I FasilitatorGKM tahun 2012 dan 22 2013, juara IGKM 2013 tingkat Provinsi DKI Jakarta, juara I Posyandu Buah Naga Ragunan di tingkat kota Jakarta Selatan dan juara IV tingkat Provinsi DKI Jakarta, Juara II Lomba Sekolah Sehat SMP 212 Cilandak Timur tingkat kota Jakarta Selatan dan juara III tingkat Provinsi DKI Jakarta tahun 2013, Juara I SMP 107 Pejaten Barat tingkat Kota tahun 2014, juara I SMK 57 Jati Padang tingkat kota Jakarta Selatan tahun 2014 dan Juara I TOGA
RW. 01 Pasar Minggu tingkat kota Jakarta Selatan tahun 2014.

Hasil penelitian ini menemukan bahwa prevalensi ibu yang melaksanakan tehnik yang menyusui dengan benar, masih lebih banhyak dibandingkan ibu yang tehnik menyusuinya masih kurang benar. Hal ini disebabkan karena sampel yang diambil adalah ibu ibu yang masih menyusui anaknya. Kemungkinan akan berbeda hasilnya bila sampel yang diambil adalah ibu-ibu yang baru melahirkan. dimana akan lebih terlihat lagi mana yang teknik menyusuinya benar dan mana yang masih kurang benar.

\section{Kesimpulan}

Hasil penelitian penelitian ini adalah sebagian besar ibu-ibu menyusui di wilayah binaan puskesmas kecamatan pasar minggu dapat melaksanakan teknik menyusui dengan benar. Ada hubungan yang signifikan antara pengetahuan dan pendidikan kesehatan dengan pelaksanaan teknik menyusui yang benar. Pengetahuan adalah faktor yang paling dominan dalam penelitian ini.

\section{BIBLIOGRAFI}

Angsuko, D. V. (2009). Hubungan Pengetahuan Ibu Tentang Cara Menyusui Dengan Perilaku Menyusui Bayi Usia 0-6 Bulan Di Bidan Yuda, Klaten. Google Scholar

Arifiati, N. (2017). Analisis Faktor Yang Mempengaruhi Pemberian Asi Ekslusif Pada Bayi Di Kelurahan Warnasari Kecamatan Citangkil Kota Cilegon. Prosiding Seminar Nasional Ikakesmada "Peran Tenaga Kesehatan Dalam Pelaksanaan Sdgs," 129-135. Google Scholar

Asiah, N. (2016). Pengetahuan Ibu Tentang Pemberian Asi Eksklusif Di Desa Bojong, Karang Tengah, Cianjur. Arkesmas (Arsip Kesehatan Masyarakat), 1(1). Google Scholar 
Faktor Faktor yang Berhubungan dengan Pelaksanaan Teknik Menyusui dengan Benar pada Ibu Menyusui

Balqis, W. D. (2020). Hubungan Dukungan Suami Terhadap Pemberian Asi Eksklusif Di Wilayah Kerja Puskesmas Rawat Inap Tanjung Bintang Lampung Selatan Tahun 2020. Poltekkes Tanjungkarang. Google Scholar

Hani, R. U. (2014). Hubungan Dukungan Suami Terhadap Keberhasilan Pemberian Asi Eksklusif Pada Ibu Primipara Di Wilayah Kerja Puskesmas Pisangan. Google Scholar

Hayati, S. (2018). Penerapan Teknik Menyusui Bayi Pada Ibu Post Partum Di Bpm Ernita Pekanbaru Tahun 2017. Jurnal Medika Usada, 1(2), 1-6. Google Scholar

Kemenkes, R. I. (2018). Hasil Utama Riskesdas 2018. In Online) Http://Www. Depkes. Go. Id/Resources/Download/InfoTerkini/Materi_Rakorpop_2018/Hasil\% 20riskesdas (Vol. 202018). Google Scholar

Maghfiroh, R. D. N. (2018). Penatalaksanaan Asuhan Gizi Pada Balita Kurang Energi Protein (Kep) Di Rumah Pemulihan Gizi Kabupaten Situbondo. Google Scholar

Merryana Adriani, S. K. M. (2016). Peranan
Gizi Dalam Siklus Kehidupan. Prenada Media. Google Scholar

Muliawati, S. (2016). Studi Deskriptif Pelaksanaan Teknik Menyusui Bayi Tunggal Di Rb Mta Semanggi Surakarta Tahun 2011. Jurnal Infokes Universitas Duta Bangsa Surakarta, 2(1). Google Scholar

Nursalam. (2011). Proses Dan Dokumentasi Keperawatan. Jakarta: Salemba Medik. Google Scholar

Sembiring, J. B. (2019). Buku Ajar Neonatus, Bayi, Balita, Anak Pra Sekolah. Deepublish. Google Scholar

Wilopo, S. A. (2009). Pola, Tren, Dan Perbedaan Praktik Menyusui Di Indonesia: Analisis Deskriptif Peran Modernisasi Dan Budaya Tradisional Dari Data Survei Demografi Kesehatan Indonesia 2007. Jurnal Gizi Klinik Indonesia, 6(1), 42-51. Google Scholar

Wulandari, F. I., \& Iriana, N. R. (2016). Karakteristik Ibu Menyusui Yang Tidak Memberikan Asi Eksklusif Di Upt Puskesmas Banyudono I Kabupaten Boyolali. Jurnal Infokes Universitas Duta Bangsa Surakarta, 3(2). Google Scholar

\section{Copyright holder:}

Bara Miradwayana, Suryati, Fenti Hasnani (2021)

First publication right:

Jurnal Health Sains

This article is licensed under: 